\title{
ON A NEW MUTILLID PARASITE OF GLOSSINA MORSITANS.
}

\author{
By Rowland E. Turner.
}

\section{Mutilla auxiliaris, sp. nov.}

․ Nigra; thorace brevissimo, fusco-ferrugineo; tergitis tribus basalibus fascia apicali angusta pallide aureo-sericea; area pygidiali nulla.

๙. Niger; prothorace, mesonoto, scutelloque ferrugineis; tergitis quatuor basalibus albido-fimbriatis; alis fuscis, basi dilutioribus, posticis basi hyalinis, venis nigris, calcaribus intermediis posticisque pallidis.

Long. ㅇ, $5 \mathrm{~mm}$.; $0^{7}, 7 \mathrm{~mm}$.

․ Mandibles simple ; antennae rather stout; second joint of the flagellum short, scarcely longer than the third; the apical joint rather slender, longer than the penultimate. Head rugosely punctured; eyes oval, situated nearer to the base of
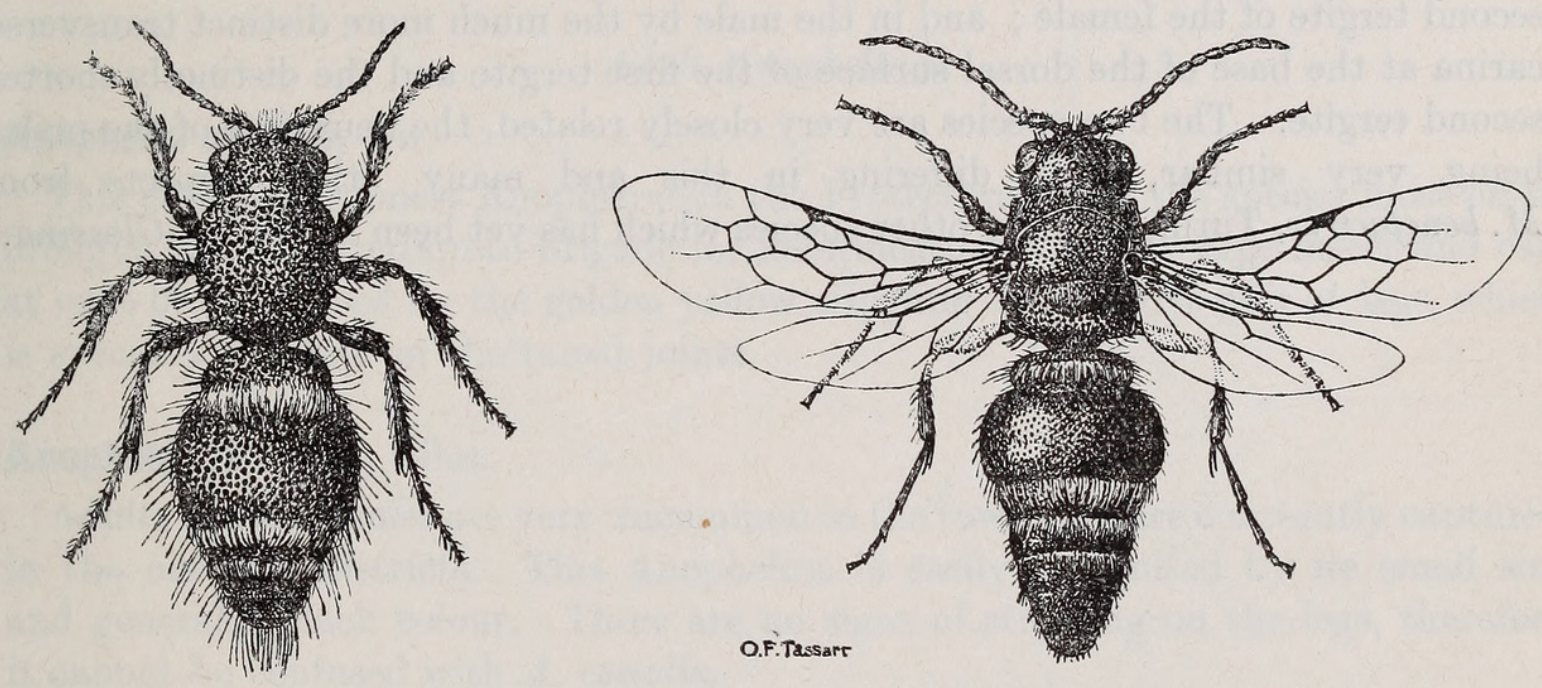

Fig. 1. Mutilla auxiliaris, Turner, sp. n., 우

the mandibles than to the hind margin of the head. The whole insect rather sparsely clothed with long blackish hairs. Thorax as broad as the head, punctured-rugose, almost as broad in the middle as long; the sides distinctly, but not strongly, convex; the anterior margin not quite straight, widely and very shallowly emarginate, the posterior slope rather abrupt, no scutellar tubercle, the sides of the apical slope with several minute teeth. Abdomen strongly punctured, the punctures more or or less confluent longitudinally; first tergite broad, transverse, almost as broad as the second, abruptly truncate anteriorly; second tergite as broad in the middle as long, the sides distinctly, but not very strongly convex; no pygidial area. Hind tibiae with a row of three spines; tarsal ungues simple.

o. Clypeus strongly concave, shallowly emarginate at the apex; bordered laterally by carinae which converge towards the base, the apical margin with several pale setae. Mandibles bidentate on the right side, tridentate on the left ; labrum transverse. Head closely punctured, the clypeus smooth and shining; antennal tubercles strongly developed, the front with an obscure longitudinal sulcus which does 
not extend to the anterior ocellus. Second joint of the flagellum distinctly shorter than the third, the fourth slightly longer then the third. Pronotum and mesonotum evenly and rather strongly punctured, the mesonotum short and broad; scutellum more coarsely punctured; median segment short and broad, very coarsely reticulate. Abdominal tergites rather less strongly punctured than the thorax; first tergite short, transverse, narrower than the second which is very broad, being nearly three times as broad at the apex as long, with the sides strongly convex ; seventh tergite broadly subtruncate at the apex. Second abscissa of the radius longer than the third, first transverse cubital nervure curved inwards, second curved outwards, first recurrent nervure received close to the middle of the second cubital cell, second beyond two-thirds from the base of the third cubital cell.

Portuguese East Africa: Kanezi, Mossurise district, vii. 1918 (C. F. M. Swynnerton).

Bred from puparia of Glossina morsitans, 5 우, 1 s.

Allied to M. glossinae, Turn., but easily distinguished by the shorter thorax and second tergite of the female ; and in the male by the much more distinct transverse carina at the base of the dorsal surface of the first tergite and the distinctly shorter second tergite. The two species are very closely related, the neuration of the males being very similar, both differing in this and many other respects from M. benefactrix, Turn., the only other species which has yet been bred from Glossina. 


\section{$2 \mathrm{BHL}$ Biodiversity Heritage Library}

Turner, Rowland E. 1920. "On a new mutillid parasite of Glossina morsitans." Bulletin of entomological research 10, 327-328. https://doi.org/10.1017/s0007485300044187.

View This Item Online: https://www.biodiversitylibrary.org/item/110745

DOI: https://doi.org/10.1017/S0007485300044187

Permalink: $\underline{\text { https://www.biodiversitylibrary.org/partpdf/49475 }}$

\section{Holding Institution}

Smithsonian Libraries

\section{Sponsored by}

Biodiversity Heritage Library

\section{Copyright \& Reuse}

Copyright Status: Public domain. The BHL considers that this work is no longer under copyright protection.

This document was created from content at the Biodiversity Heritage Library, the world's largest open access digital library for biodiversity literature and archives. Visit BHL at https://www.biodiversitylibrary.org. 